\title{
Endocrine and metabolic responses to glucose, insulin, and adrenocorticotropin infusions in early-lactation dairy goats of high and low milk yield
}

\author{
F. Zamuner, ${ }^{1 *} \odot$ A. W. N. Cameron, ${ }^{2}$ E. K. Carpenter, ${ }^{1,2}$ B. J. Leury, ${ }^{1} \oplus$ and K. DiGiacomo ${ }^{1} \oplus$ \\ ${ }^{1}$ Faculty of Veterinary and Agricultural Sciences, the University of Melbourne, Parkville, Victoria 3010, Australia \\ ${ }^{2}$ Meredith Dairy Pty Ltd., 106 Cameron Rd, Meredith, Victoria 3333, Australia
}

\begin{abstract}
This experiment aimed to examine endocrine and metabolic responses to glucose, insulin, and adrenocorticotropin (ACTH) infusions in early-lactation dairy goats of different levels of milk production (LMP). Goats were grouped as either high $(\mathrm{HY} ; 4.0 \mathrm{~L} / \mathrm{d}, \mathrm{n}$ $=13$ ) or low milk yield $(\mathrm{LY} ; 2.4 \mathrm{~L} / \mathrm{d}, \mathrm{n}=13)$. Individual milk yield $(\mathrm{L} / \mathrm{d})$ and dry matter intake (DMI; $\mathrm{kg} / \mathrm{d}$ ) were measured daily. Concentration $(\mathrm{m} M)$ of glucose, fatty acids, and $\beta$-hydroxybutyrate, percent of milk fat and protein, body weight (BW; $\mathrm{kg}$ ), and body condition score (BCS) were assessed weekly (from 2-6 wk postpartum). An intravenous glucose tolerance test (IVGTT), an insulin tolerance test (ITT), and an ACTH stimulation test were carried out at 43, 44, and $45 \pm 0.7 \mathrm{~d}$ in milk, respectively. The HY goats had greater milk yield $(+67 \%)$, energy-corrected milk $(\mathrm{ECM} ;+70 \%)$, DMI $(+28 \%)$, ratio of ECM output to metabolic BW $(+67 \%)$, and feed efficiency $(+25 \%)$, but lesser BCS than LY goats (2.4 vs. 2.6). The DMI (\% of BW) was moderately correlated with ECM (r = $0.70)$ and negatively correlated with BCS $(\mathrm{r}=-0.57)$. At the time of the IVGTT, HY goats had lesser basal insulin and glucose than LY goats. However, results from IVGTT and ITT indicate that the sensitivity of peripheral tissues to insulin was unaffected by LMP. Compared with LY, HY goats had lesser insulin secretion $(-52 \%)$ and greater insulin clearance rate $(+47 \%)$ after glucose infusion. The ITT and ACTH stimulation test results show that both the growth hormone response to insulin and the cortisol response to ACTH were unaffected by LMP. Also, basal plasma concentrations of GH and cortisol were not correlated with glucose and fatty acids concentrations or any performance traits. Collectively, our results suggest that differences between HY and LY goats, concerning milk yield and
\end{abstract}

Received April 1, 2020.

Accepted July 17, 2020.

*Corresponding author: fzamuner@student.unimelb.edu.au feed efficiency, were probably more closely related to differences in insulin secretion and clearance than to differences in peripheral tissue responsiveness to the effects of catabolic and anabolic hormones.

Key words: insulin sensitivity, nutrient partitioning, energy metabolism, milk production

\section{INTRODUCTION}

Improved milk production-efficiency is of great economic importance in the dairy industry. One of the most important characteristics determining the enhanced potential for milk production is the maternal ability to partition proportionately more of absorbed nutrients toward milk synthesis, and less into body reserves (Baumgard et al., 2017). Therefore, a deeper understanding of how different factors (e.g., environment, genotype, physiological state, nutrition) influence maternal nutrient partitioning is essential for developing optimized strategies that could enhance milk yield or reduce production costs, without compromising herd health and welfare (Kiplagat et al., 2012; Friggens et al., 2013).

The regulation of nutrient partitioning is orchestrated by complex interactions between a plethora of hormones; among them, insulin, growth hormone (GH), and glucocorticoids have a major effect on the regulation of nutrient supply in ruminants (Bell and Bauman, 1997; Baumgard et al., 2017). For instance, in dairy cows, greater milk yield is associated with reduced insulin and elevated GH concentrations (Bell and Bauman, 1997; Veerkamp et al., 2003; Lucy et al., 2009), decreased cortisol responses after ACTH administration (Beerda et al., 2004), intensified mobilization of body lipid stores (Veerkamp et al., 2003), and a greater degree of insulin resistance (De Koster and Opsomer, 2013; Cincović et al., 2018).

Moreover, similar to observations in dairy cows, a recent study in early-lactation goats found significant differences in endocrine and metabolic profiles between dairy goats of high and low milk yield (Zamuner et al., 
2020). We demonstrated that high-yielding goats have lesser concentrations of insulin and glucose, greater concentrations of $\mathrm{GH}$, fatty acids, and $\mathrm{BHB}$, and greater BW loss than their lower-yielding counterparts.

However, in contrast to the extensive information on endocrine regulation of nutrient partitioning in dairy cows (De Koster and Opsomer, 2013; Baumgard et al., 2017; Cincović et al., 2018), little is known about mechanisms controlling the nutrient supply to the mammary gland in early-lactation goats. Relatively few studies have examined changes in insulin responsiveness in dairy goats with respect to physiological state (Debras et al., 1989), genetic merit for milk production (Cronjé et al., 2000), and energy intake (Schmidely et al., 1999). However, underlying endocrine and metabolic mechanisms that determine greater milk yield in goats of the same breed and plane of nutrition are yet to be elucidated.

Therefore, this experiment aimed to investigate metabolic and endocrine responses in early-lactation dairy goats. To determine whether there are discernible differences in metabolic responses according to the level of milk production (LMP), goats of high $(\mathbf{H Y})$ and low milk yield (LY) were subjected to 3 metabolic challenges performed at approximately 6 wk postpartum: an intravenous glucose tolerance test (IVGTT), an intravenous insulin tolerance test (ITT), and an intravenous ACTH stimulation test (AST). We hypothesized that, in comparison to LY, HY goats would exhibit (1) lesser circulating insulin concentrations following bolus glucose infusion, (2) reduced glucose and fatty acids responses to an insulin infusion, and (3) decreased cortisol response to ACTH administration.

\section{MATERIALS AND METHODS}

All experimental procedures were approved by the Faculty of Veterinary and Agricultural Sciences Animal Ethics and Welfare Committee of The University of Melbourne, Australia (No 1714287.1).

\section{Animals, Nutrition, and Husbandry}

This experiment was conducted at Meredith Dairy commercial farm (Meredith, Australia, 37 $50^{\prime} \mathrm{S}$; $144^{\circ}$ $\left.04^{\prime} \mathrm{E}\right)$. The experiment used 26 clinically healthy Saanen dairy goats in second or third parity that kidded in March 2018 (early autumn). Goats were selected based on milk yield from 0 to 10 DIM and total milk yield in the previous lactation. Then, at the end of wk 1 (11 $\pm 4.2 \mathrm{~d}$; mean $\pm \mathrm{SD}$ ), the 13 highest- and 13 lowestyielding goats were randomly allocated to individual stalls in an elevated shed (north-south oriented with the open side facing east), where they were kept under natural lighting and ventilation conditions. The shed had 2 rows of 15 individual stalls $\left(15 \mathrm{~m}^{2}\right)$ equipped with drinkers, wooden walls, and slatted floors. Plastic feeders were attached to the metal-framed gates opening to the center aisle, from which goats could make audio-visual-olfactory contact. Goats were ad libitum fed a TMR once daily at around $0900 \mathrm{~h}$ and had free access to water during the experimental period (from 2-6 wk postpartum). The proportions (DM basis) of the components in the diet were barley (37\%), lupins $(22 \%)$, ryegrass silage $(28 \%)$, and commercial pellets (11\%; $25 \% \mathrm{CP}, 14 \mathrm{MJ}$ of ME/kg, 29\% NDF, $65 \mathrm{~g}$ of $\mathrm{Ca} / \mathrm{kg}, 16 \mathrm{~g}$ of $\mathrm{P} / \mathrm{kg}$ ). The nutrient composition (per $\mathrm{kg}$ of DM) of the diet was $32 \% \mathrm{NDF}, 17 \% \mathrm{CP}, 13 \mathrm{MJ}$ of $\mathrm{ME}, 9.4 \mathrm{~g}$ of $\mathrm{Ca}$, and $4.3 \mathrm{~g}$ of $\mathrm{P}$.

\section{Measurements}

Goats were milked twice daily, and individual milk volume was recorded at 0800 and $1600 \mathrm{~h}$ in a 36-sided herringbone system fitted with automatic cup removers and in-line electronic milk meters (MidiLine SG Parlor, DeLaval Inc., Colac, VIC, Australia). Feed offered and refused was weighed daily during the experimental period. Weekly adjustments were made to the amount of TMR offered to maintain a minimum $5 \%$ refusal rate, ensuring ad libitum feeding.

Individual milk samples $(10 \mathrm{~mL})$ were collected during morning milking at the beginning of wk 2, 3, 4, and 5. Samples were preserved with bronopol (Broad Spectrum Microtabs II, D and F Control Systems, Inc., Norwood, MA) and transported on ice $\left(4^{\circ} \mathrm{C}\right)$ to the laboratory at Herd Improvement Co-Operative (HICO, Colac, VIC, Australia) for determination of milk fat, protein, and lactose using a NexGen milk analyzer (Bentley, Chaska, MN). Immediately after milking (and before feeding), blood samples were collected via jugular venipuncture using vacuum tubes $(10 \mathrm{~mL})$ coated with lithium-heparin (BD, Plymouth, Devon, UK), immediately placed on ice, and centrifuged $(1,250 \times$ $\mathrm{g}, 4^{\circ} \mathrm{C}$ ) for $12 \mathrm{~min}$ within $1 \mathrm{~h}$ after collection. Isolated plasma was stored at $-20^{\circ} \mathrm{C}$ until analysis.

Goat BW and BCS were assessed on the same day of milk and blood testing, and at the beginning of wk 6 (always before feeding and after the morning milking). The BCS was scored by the same person, adopting a 6-point scale method (Villaquiran et al., 2004).

\section{Intravenous Challenges}

On the morning of d 42 (wk 6) after an overnight fast, a 14-gauge, 3.25-inch angiocath catheter (BD, 
Sydney, NSW, Australia) was inserted approximately $8 \mathrm{~cm}$ into the jugular vein and then secured to the skin using medical tape and superglue. A 22-cm plastic catheter extension with a Luer lock (Heidelberg extension tubing; B. Braun, Bethlehem, PA) prefilled with heparinized saline $(50 \mathrm{U} / \mathrm{L})$ was secured to the catheter. The catheter was flushed with 8 to $10 \mathrm{~mL}$ of heparinized saline $(50 \mathrm{U} / \mathrm{L})$ and sealed with a Safesite (B. Braun). When not frequently in use, the patency of the catheter was maintained by flushing with 8 to 10 $\mathrm{mL}$ of heparinized saline (50 U/L) twice daily. During blood sampling procedures, the catheter was flushed with heparinized saline $(25 \mathrm{U} / \mathrm{L})$ immediately after every blood sample collection. Food was withheld for $12 \mathrm{~h}$ before each challenge. On d 43, a $50 \%$ glucose solution was administered intravenously at $0.3 \mathrm{~g}$ of glucose/ $\mathrm{kg}$ of $\mathrm{BW}$, and blood samples were collected at -30 , $-15,-1,2,3,4,5,6,8,10,12,14,16,18,20,25,30$, $35,40,60,90,120,150,180,210,220$, and $240 \mathrm{~min}$ relative to glucose infusion (Marett et al., 2015). On d 44, insulin [Actrapid, human insulin (92\% homologous to caprine insulin), Novo Nordisk Pharmaceuticals Pty Ltd., Baulkham Hills, NSW, Australia] was administered intravenously at $0.125 \mathrm{IU} / \mathrm{kg}$ of $\mathrm{BW}$, and blood samples were collected at $-30,-15,-1,5,10,15,20$, $25,30,35,40,45,50,55,60,70,90,120,150,180$, $210,240,270$, and $300 \mathrm{~min}$ relative to insulin infusion (Marett et al., 2017). On d 45, a synthetic analog of ACTH (Synacthen, Novartis, Sydney, NSW, Australia) was administered intravenously at $0.2 \mathrm{IU} / \mathrm{kg}$ of $\mathrm{BW}$, and blood samples were collected at $-30,-15,-1$, $5,10,15,20,25,30,35,45,60,75,90,120,150,180$, and 210 min relative to ACTH infusion (DiGiacomo et al., 2018). Catheters were flushed with $10 \mathrm{~mL}$ of 100 $\mathrm{IU} / \mathrm{L}$ of heparinized saline at the end of each challenge period. All blood samples were collected into vacuum tubes $(10 \mathrm{~mL})$ coated with lithium-heparin (BD), immediately placed on ice, and centrifuged $(1,250 \times g$, $4^{\circ} \mathrm{C}$ ) for 12 min within $1 \mathrm{~h}$ after collection. Isolated plasma was stored at $-20^{\circ} \mathrm{C}$ until analysis.

\section{Laboratory Analyses}

The whole-blood concentration of BHB was measured using a hand-held meter (FreeStyle Optium Precision Neo, Abbott Diabetes Care Ltd., Witney, UK) before plasma separation. Plasma fatty acids concentrations were measured using a commercially available kit [NEFA-C ACS-ACOD Method; modified as per the methods of Johnson and Peters (1993), Wako Pure Chemical Industries, Ltd., Osaka, Japan]. Plasma glucose concentrations were measured using a commercially available kit (Infinity Glucose Oxidase
Liquid, Thermo-Scientific, Middletown, VA). Plasma insulin concentrations were measured using an RIA kit (Porcine Insulin Cat. \# PI-12K, Millipore Corporation, Billerica, MA) validated in goats by Maia-Nogueira (2015). Plasma GH concentrations (at $-30,-15,-1,5$, $10,15,25,35,60,90,120$, and 180 min relative to insulin infusion) and cortisol concentrations (at $-30,-15$, $-1,15,30,45,60,120$, and $180 \mathrm{~min}$ relative to $\mathrm{ACTH}$ infusion) were measured using the methods described by Thomas et al. (1990). Assay sensitivity (limit of detection) ranged between 0.4 to $0.5 \mathrm{mU} / \mathrm{L}$ for insulin, 0.2 to $0.3 \mathrm{ng} / \mathrm{mL}$ for $\mathrm{GH}$, and 0.13 to $0.29 \mathrm{ng} / \mathrm{mL}$ for cortisol. Every sample (except for BHB) was assayed in duplicate. Intra- and interassay coefficients of variation were $<7.0 \%$ and $<3.5 \%$ for glucose, $<6.0 \%$ and $<3.0 \%$ for fatty acids, $<10 \%$ and $<4.1 \%$ for insulin, $<10 \%$ and $<4.3 \%$ for $\mathrm{GH}$, and $<10 \%$ and $<5.2 \%$ for cortisol.

\section{Calculations and Statistical Analyses}

At the end of each week, the total DMI (kg/goat), milk yield (L/goat), content (\%) of milk fat and protein, and BW were used to calculated calculate average ECM, BW efficiency (BWE, \%), DMI as a percentage of BW, and feed efficiency $(\mathbf{F E}, \mathrm{kg} / \mathrm{kg})$. Average ECM $(\mathrm{kg} / \mathrm{d})$ was calculated using the equation ECM $=$ milk $(\mathrm{kg}) \times[0.3246+(0.1356 \times$ percentage of fat + $0.0704 \times$ percentage of protein)], according to Cai et al., (2018). The BWE was calculated using the equation $\mathrm{BWE}=\mathrm{ECM} / \mathrm{BW}^{0.75} \times 100$ (Köck et al., 2018). The DMI (\% BW) was calculated as DMI $(\mathrm{kg} / \mathrm{d}) / \mathrm{BW}$ $(\mathrm{kg})$. The FE ratio was calculated as ECM $(\mathrm{kg} / \mathrm{d}) / \mathrm{DMI}$ $(\mathrm{kg} / \mathrm{d})$. Because goats kidded over the course of $2 \mathrm{wk}$, DIM (in relation to each day of sampling) was determined for each goat by subtracting the date of kidding from the date of sampling.

Metabolic Challenges. Baseline concentrations for the studied analytes were calculated as the mean concentration of the 3 blood samples taken before infusions. Plasma hormones and metabolite responses were analyzed for the area under the curve (AUC) using a linear trapezoidal summation between successive pairs of metabolite concentrations after correcting for baseline concentrations. Peak and nadir concentrations, percentage change from baseline, clearance rates $(\mathbf{C R})$, and time $(\mathbf{T})$ to reach half-life $\left(\mathbf{T}_{1 / 2}\right)$, peak $\left(\mathbf{T}_{\text {peak }}\right)$, and basal $\left(\mathbf{T}_{\text {basal }}\right)$ concentrations were calculated for each goat, and mean values are reported for each specific treatment group. Values were calculated using the following formulas, as previously described by Pires et al. (2007):

$$
\mathrm{CR}=[(\ln [\mathrm{ta}]-\ln [\mathrm{tb}]) /(\mathrm{tb}-\mathrm{ta})] \times 100,
$$


where [ta] is the concentration of the metabolite at time a (ta) and $[\mathrm{tb}]$ is the concentration of metabolite at time $\mathrm{b}(\mathrm{tb})$.

$\mathrm{T}_{1 / 2}$ glucose $=\left[\ln (2) / \mathrm{CR}_{2-30}\right.$ glucose $] \times 100$,

$\mathrm{T}_{\text {basal }}$ glucose $=[(\ln [2 \mathrm{~min}]-\ln [240 \mathrm{~min}]) /$

$\mathrm{CR}_{2-30}$ glucose] $\times 100$,

$\mathrm{T}_{\text {basal }}$ insulin $=[(\ln [2 \mathrm{~min}]-\ln [240 \mathrm{~min}]) /$

$\mathrm{CR}_{20-120}$ insulin] $\times 100$,

Change $=[($ peak $($ or nadir $)$ concentration

- basal concentration)/basal concentration] × 100 .

MINMOD Parameters. Key indices of glucoseinsulin dynamics were calculated using MINMOD Millennium software (MINMOD Inc., Pasadena, CA; Boston et al., 2003). The parameters and indices that were output by the MINMOD software were: $\mathbf{G}_{\mathrm{B}}=$ basal glucose concentration pre-infusion $(\mathrm{m} M) ; \mathbf{I}_{\mathbf{B}}=$ basal insulin concentration pre-infusion $(\mathrm{mU} / \mathrm{L})$; $\mathbf{S G}$ $=$ glucose effectiveness $\left(\mathrm{min}^{-1}\right)$, which refers to the capacity of glucose to mediate its own uptake; SI = insulin sensitivity $\left[(\mathrm{mU} / \mathrm{L})^{-1} \cdot \mathrm{min}^{-1}\right]$, which refers to the capacity of insulin to promote glucose uptake; AIR $=$ acute insulin response to glucose $\left(\mathrm{mU} \cdot \mathrm{L}^{-1} \cdot \mathrm{min}^{-1}\right)$, which addresses the adequacy of insulin secretion in response to a glucose bolus; DI $=$ disposition index $($ AIR $\times \mathrm{SI})$, which represents the ability of the islet cells to secrete insulin.

Other indices that are included in the MINMOD Millennium output are derived from the Homeostatic assessment model (HOMA): IR $=$ insulin resistance $\left(\mathrm{m} M \cdot \mathrm{mU} \cdot \mathrm{L}^{-2}\right)$, calculated by the equation: (IB $\times$ GB) $/ 22.5 ; \quad \mathbf{B C F}=$ pancreatic $\beta$-cell function $(\mathrm{mU} /$ $\mathrm{m} M)$, calculated by the equation: $(20 \times \mathrm{IB}) /(\mathrm{GB}-$ $3.5)$.

Statistical analyses were performed using Minitab software (version 18.1; Minitab Inc., State College, PA). All outcome variables were screened for normality by calculation of kurtosis and skewness and by visual assessment of standardized residuals distribution. Data from repeated measurements were analyzed using the ANOVA mixed effects model (restricted maximum likelihood and 2-sided 95\% CI), and data from nonrepeated measurements were analyzed using the ANOVA general linear model (2-sided 95\% CI) of Minitab. All models included the fixed effect of LMP and the random effect of goat. Parity, BW, BCS, DIM, and the time of the day when blood was collected were tested in all models as covariates and retained when significant $(P$
$<0.05$ ). Models analyzing data derived from metabolic challenges used values of BW, BCS, and DIM measured at wk 6. Bonferroni method with 95\% CI was used for pairwise comparisons. Statistical significance was declared at $P<0.05$, and values of $P<0.1$ were considered a trend toward significance. Spearman rho correlation was used to examine relationships between variables of interest. Correlations between variables measured weekly included 4 observations per goat. Correlations between values derived from metabolic challenges and performance data used values measured at wk 6 .

Data Presentation. Results for log-transformed variables were reported after back-transformation. Data are presented as mean \pm standard error of the mean unless declared otherwise.

\section{RESULTS}

The HY goats had substantially greater milk yield than LY goats $(4.0$ vs. $2.4 \mathrm{~L} / \mathrm{d} ; P<0.001)$. However, for all variables, no interaction effect of LMP $\times$ week was detected. The main effect of LMP on average performance and metabolite concentrations from wk 2 to 5 are depicted in Table 1.

The HY and LY goats were homogeneous for parity (2.5 vs. $2.5 ; P=0.855)$ and age (34.7 vs. $34.2 \mathrm{mo} ; P=$ 0.869 ). However, average DIM (at wk 2 ) was $4 \mathrm{~d}$ greater in HY than LY goats ( 15 vs. 11 DIM; $P=0.008$ ). The HY goats had greater ECM $(+70 \% ; P<0.001)$, greater DMI both on a kilogram $(+28 \% ; P<0.001)$ and percent $\mathrm{BW}$ basis $(+30 \%$; $P<0.001)$, greater $\mathrm{BWE}$ $(+67 \% ; P<0.001)$, and greater $\mathrm{FE}(+25 \% ; P=0.001)$ than LY goats. Mean BCS was greater in LY than HY goats (2.6 vs. $2.4 ; P=0.016$ ), and although the ADG from wk 2 to 6 tended to be less in HY than in LY goats (ADG; -96 vs. $-12 \mathrm{~g} / \mathrm{d} ; P=0.086$ ), we did not observe significant changes in BW for both HY and LY goats during the same period $(\mathrm{HY}=67.2$ vs. $66.8 \mathrm{~kg}$; $P>0.1$, and $\mathrm{LY}=66.7$ vs. $67.2 \mathrm{~kg} ; P>0.1$, for wk 2 vs. wk 6 , respectively). The HY goats had greater milk protein than LY goats (3.3 vs. $3.1 \% ; P=0.020)$, but average milk fat $(4.6 \pm 0.19 \%)$ and lactose $(5.2 \pm$ $0.06 \%$ ) were similar between groups. Plasma fatty acids concentration was greater $(+34 \% ; P<0.001)$ in $\mathrm{HY}$ than LY goats, but glucose and BHB were not affected by LMP.

Correlations between performance variables are listed in Table 2. Even though ECM was correlated with DMI $(\mathrm{r}=0.70)$, and DMI was correlated with BWE $(\mathrm{r}=$ 0.74), BW was not correlated with ECM. We also observed a negative relationship between BCS and DMI, ECM, FE, and BWE. Concentrations of BHB and fatty acids were positively correlated $(P<0.01)$ with ECM 
Table 1. Effects of level of milk production on performance traits and metabolite concentrations in highyielding $(\mathrm{HY} ; \mathrm{n}=13)$ and low-yielding $(\mathrm{LY} ; \mathrm{n}=13)$ commercial dairy goats from 14 to $42 \mathrm{DIM}^{1}$

\begin{tabular}{lcccccc}
\hline & & & & \multicolumn{3}{c}{$P$-value } \\
\cline { 5 - 6 } Item $^{2}$ & & & & & \\
& HY & LY & SED $^{3}$ & Level (L) & Week (W) & $\mathrm{L} \times \mathrm{W}$ \\
\hline Milk & & & & & & \\
Yield (L/d) & 4.0 & 2.4 & 0.18 & $<0.001^{*}$ & 0.073 & 0.193 \\
Fat (\%) & 4.6 & 4.6 & 0.19 & 0.986 & 0.776 & 0.839 \\
Protein (\%) & 3.3 & 3.1 & 0.06 & $0.012^{*}$ & $<0.001^{*}$ & 0.056 \\
Lactose (\%) & 5.2 & 5.2 & 0.06 & 0.473 & 0.728 & 0.123 \\
ECM (kg/d) & 4.6 & 2.7 & 0.20 & $<0.001^{*}$ & 0.073 & 0.193 \\
DMI (kg/d) & 2.3 & 1.8 & 0.14 & $<0.001^{*}$ & 1.016 & 0.984 \\
DMI (\% of BW) & 3.5 & 2.7 & 0.20 & $<0.001^{*}$ & $0.012^{*}$ & 0.970 \\
FE (kg/kg) & 2.0 & 1.6 & 0.12 & $0.001^{*}$ & $<0.001^{*}$ & 0.685 \\
BW (kg) & 66 & 67 & 2.9 & 0.688 & 0.057 & 0.343 \\
BCS & 2.4 & 2.6 & 0.08 & $0.016^{*}$ & 0.075 & 0.974 \\
BWE (\%) & 20 & 12 & 0.9 & $<0.001^{*}$ & 0.017 & 0.079 \\
ADG (g/d) & -96 & -12 & 46.5 & 0.086 & $<0.001^{*}$ & 0.194 \\
Fatty acids (mM) & 0.5 & 0.4 & 0.05 & $0.021^{*}$ & $<0.001^{*}$ & 0.199 \\
Glucose (mM) & 3.4 & 3.5 & 0.14 & 0.532 & 0.295 & 0.486 \\
BHB (mM) & 0.4 & 0.4 & 0.04 & 0.168 & 0.076 & 0.096 \\
\hline
\end{tabular}

${ }^{1}$ Values are restricted maximum likelihood means.

${ }^{2} \mathrm{ECM}=$ milk $(\mathrm{kg}) \times[0.3246+(0.1356 \times \%$ of fat $+0.0704 \times \%$ of protein $)]$ according to Cai et al. (2018);

$\mathrm{FE}=$ feed efficiency rate $[\mathrm{ECM}(\mathrm{kg} / \mathrm{d}) / \mathrm{DMI}(\mathrm{kg} / \mathrm{d})] ; \mathrm{BWE}=\mathrm{BW}$ efficiency $\left[\mathrm{ECM}(\mathrm{kg} / \mathrm{d}) / \mathrm{BW}^{0.75}(\mathrm{~kg}) \times 100\right.$ (Köck et al., 2018).

${ }^{3} \mathrm{SED}=$ standard error of differences.

*Statistically significant $(P<0.05)$.

$(\mathrm{r}=0.33$ and 0.28$), \mathrm{FE}(\mathrm{r}=0.38$ and 0.25$)$, and $\mathrm{BWE}$ $(\mathrm{r}=0.33$ and 0.27$)$, and were negatively correlated $(P$ $<0.01)$ with BCS $(\mathrm{r}=-0.32$ and -0.22$)$. Fatty acids concentration was correlated with glucose $(\mathrm{r}=-0.26$; $P<0.01)$ and BHB $(\mathrm{r}=0.32 ; P<0.01)$.

\section{Intravenous Glucose Tolerance Test}

Response curves for insulin, glucose, and fatty acids concentrations after a glucose infusion in HY and LY goats are presented in Figure 1. Results of the comparisons of analyzed IVGTT variables between HY and LY goats are given in Table 3. Before the IVGTT, LY had greater basal glucose $(+13 \% ; P=0.046)$ and insulin $(+130 \% ; P=0.008)$ than HY goats, but there was no difference in basal fatty acids. We observed an LMP $\times$ time interaction $(P<0.001)$ for both glucose and insulin concentration. Glucose concentration was greater $(P<0.05)$ in LY than in HY goats from 2 to 40 min postinfusion. Insulin was greater $(P<0.05)$ in LY than in HY goats from 2 to 10 and from 50 to 240 min postinfusion.

Plasma glucose concentration peaked immediately following infusion $(2 \mathrm{~min})$ in both groups. The HY goats had reduced peak glucose $(-9 \% ; P=0.009)$, lesser glucose concentration at $240 \mathrm{~min}$ (recovery; $-14 \% ; P=0.013)$, lesser glucose $\mathrm{AUC}_{0-60}(-12 \% ; P=$ $0.012)$, lesser nadir insulin $(-58 \% ; P=0.016)$, greater insulin CR from 30 to $60 \mathrm{~min}(+47 \% ; P=0.005)$, and lesser insulin concentration at $240 \min (-140 \% ; P=$ $0.004)$, and tended to have lesser peak insulin $(-32 \%$; $P=0.097)$, lesser glucose $\mathrm{AUC}_{0-120}(-18 \% ; P=0.068)$, and lesser insulin $\mathrm{AUC}_{0-120}(-37 \% ; P=0.061)$ than $\mathrm{LY}$ goats. The glucose $\mathrm{T}_{1 / 2}$, was similar $(P>0.1)$ between

Table 2. Spearman rho correlations between performance traits in commercial dairy goats from 14 to 42 DIM

\begin{tabular}{lccccc}
\hline Item $^{1}$ & ECM & DMI & FE & BWE & BW \\
\hline DMI (\% of BW) & $0.70^{* * *}$ & & & & \\
FE (kg $/ \mathrm{kg})$ & $0.61^{* * *}$ & NS & & & \\
BWE (\%) & $0.95^{* * *}$ & $0.74^{* * *}$ & $0.65^{* * *}$ & & \\
BW (kg) & NS & $-0.17^{\dagger}$ & $-0.19^{\dagger}$ & $-0.18^{\dagger}$ & \\
BCS & $-0.62^{* * *}$ & $-0.57^{* * *}$ & $-0.33^{* *}$ & $-0.66^{* * *}$ & NS \\
\hline
\end{tabular}

${ }^{1} \mathrm{ECM}=$ milk $(\mathrm{kg}) \times[0.3246+(0.1356 \times \%$ of fat $+0.0704 \times \%$ of protein $)]$ according to Cai et al. (2018); $\mathrm{FE}=$ feed efficiency rate $[\mathrm{ECM}(\mathrm{kg} / \mathrm{d}) / \mathrm{DMI}(\mathrm{kg} / \mathrm{d})] ; \mathrm{BWE}=$ body weight efficiency $\left[\mathrm{ECM}(\mathrm{kg} / \mathrm{d}) / \mathrm{BW}^{0.75}\right.$ $(\mathrm{kg}) \times 100($ Köck et al., 2018)].

*** $P<0.001$; ** $P<0.01$; $P<0.05 ; \dagger P<0.1 ;$ NS $P>0.1$. 
groups $(31 \pm 1.2 \mathrm{~min})$, as were glucose $\mathrm{T}_{\text {basal }}(82 \pm 3.7$ $\min )$, insulin $\mathrm{T}_{\text {peak }}(20 \pm 1.1 \mathrm{~min})$, and insulin $\mathrm{T}_{\text {basal }}$ $(118 \pm 4.4 \mathrm{~min})$. There were no significant differences between HY and LY goats for fatty acids data derived from IVGTT.

The indices derived from the MINMOD software are presented in Table 4. Basal plasma insulin concentra-

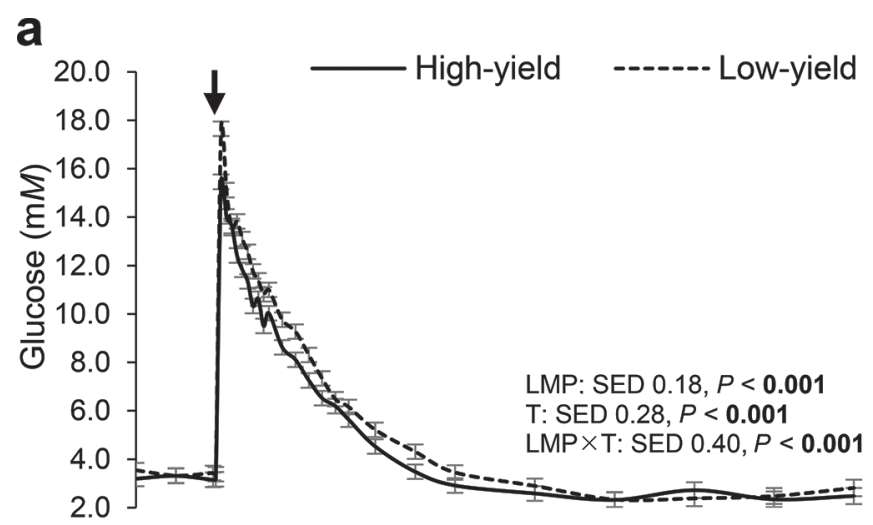

b

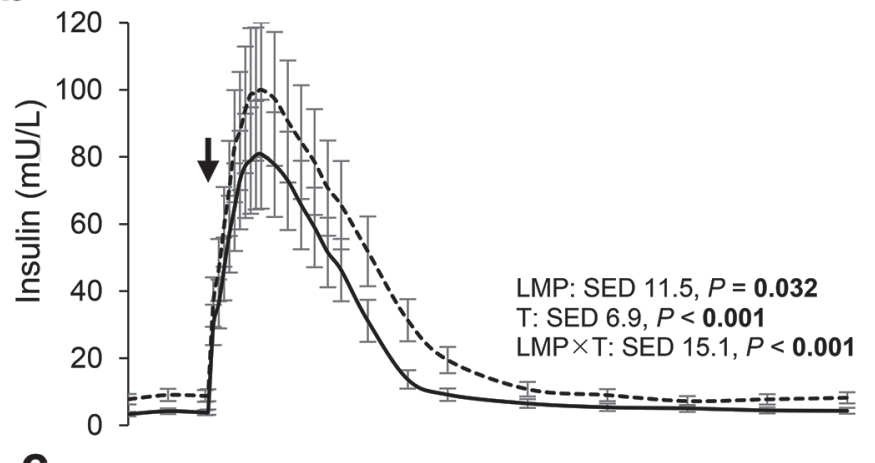

C

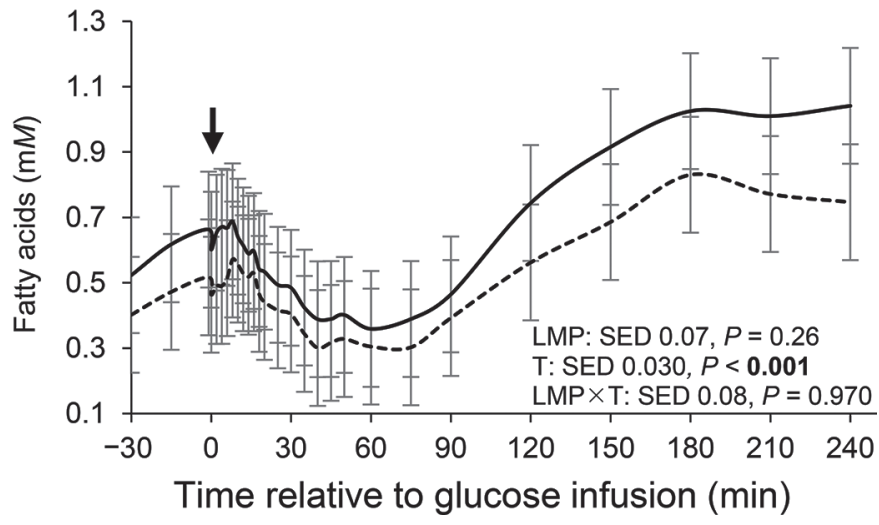

Figure 1. Responses in (a) plasma glucose, (b) insulin, and (c) fatty acid concentrations to a glucose infusion ( $0.3 \mathrm{~g}$ of $50 \%$ glucose/ $\mathrm{kg}$ of BW) at time zero $(\downarrow)$ in high-yielding $(4.0 \mathrm{~L} / \mathrm{d}, \mathrm{n}=13)$ and low-yielding $(2.4 \mathrm{~L} / \mathrm{d}, \mathrm{n}=13)$ dairy goats at $43 \pm 0.7$ DIM. Values are restricted maximum likelihood means, and error bars represent SEM. LMP = level of milk production; $\mathrm{T}=$ time of sampling; LMP $\times \mathrm{T}=$ joint effect of LMP and $\mathrm{T} ; \mathrm{SED}=$ pooled standard errors of differences. tions were 2.4-fold greater in LY $(P=0.008)$ than in HY goats, but we found no difference for basal glucose. Compared with HY goats, LY goats had 1.5-fold greater AIR $(P=0.047), 3.3$-fold greater IR $(P=0.01)$, and 7.5 -fold greater BCF $(P=0.006)$, but there were no differences in $\mathrm{S}_{\mathrm{G}}, \mathrm{S}_{\mathrm{I}}$, and DI between groups.

Correlations between IVGTT and MINMOD parameters and goat performance data are reported in Table 5 . There were no significant associations between values of glucose $\mathrm{T}_{1 / 2}$, glucose $\mathrm{CR}_{2-20}$, or any IVGTT derived value for fatty acids and performance traits. Basal insulin was negatively correlated with DMI, ECM, and BWE. Although basal glucose was not correlated with any performance parameter, glucose $\mathrm{AUC}_{0-120}$ was negatively associated with ECM, FE, and BWE. Greater insulin $\mathrm{CR}$ was associated with greater ECM, FE, and BWE. Greater $\mathrm{S}_{\mathrm{I}}$, DI, and BCF were associated with greater ECM, while greater AIR and IR were associated with reduced ECM, DMI, and BWE.

\section{Insulin Tolerance Test}

Response curves for glucose, GH, and fatty acids concentrations after an insulin infusion in HY and LY goats are presented in Figure 2. Results of the comparisons of analyzed ITT variables between HY and LY goats are given in Table 6 . No differences were detected in basal glucose, GH, or fatty acids concentrations between groups. There were no differences between HY and LY goats for glucose, GH, and fatty acids concentrations throughout the ITT or for ITT derived data. Glucose concentration began to decrease immediately after the administration of insulin, reaching $50 \%$ of basal concentration $\left(\mathrm{T}_{1 / 2}\right)$ in $26 \pm 2.0$ min postinfusion. Glucose concentration started to increase after $30 \mathrm{~min}$, returning to near baseline values $(\sim 3.5 \mathrm{mM})$ within 120 min postinfusion. Fatty acids increased sharply from 30 to $60 \mathrm{~min}$, reaching a peak of $0.6 \pm 0.05 \mathrm{~m} M$ before decreasing to a plateau of $\sim 0.4 \mathrm{~m} M$ at around $90 \mathrm{~min}$ postinfusion. Plasma GH concentrations fluctuated over time, and there was a large degree of variation in the $\mathrm{GH} \mathrm{AUC}_{0-120}$ in both groups. However, the relative increase in $\mathrm{GH}$ concentration was almost 4-fold greater $(P=0.021)$ in HY compared with LY goats. Basal GH was positively correlated with basal glucose $(\mathrm{r}=$ $0.42 ; P=0.033)$, and $\mathrm{GH}_{\text {peak }}$ was positively correlated with DMI ( $\mathrm{r}=0.47 ; P=0.016)$, but basal GH was not correlated with fatty acids or any other performance traits.

\section{Adrenocorticotropin Stimulation Test}

The cortisol response curve following the ACTH infusion is presented in Figure 3a, and the AUC for glucose, 
fatty acids, and cortisol responses at 60, 120, and 180 min after ACTH infusion are presented in Figure 3b. Results of the comparisons of analyzed AST parameters between HY and LY goats are given in Table 7 . Basal cortisol was highly variable within LMP (range; 3.0-17.7 and 1.8-20.4 ng/mL, for HY and LY goats, respectively). There were no differences in basal cortisol, glucose, or fatty acids concentrations between groups (Table 7). Also, there was no effect of LMP or LMP $\times$ time interaction on cortisol response (Figure 3a) or on cortisol-stimulated responses on glucose and fatty acids concentrations after ACTH infusion (Figure 3b). In both groups, ACTH infusion provoked a 10-fold increase in cortisol concentration within $15 \mathrm{~min}$. Cortisol concentration remained elevated until $60 \mathrm{~min}$, then it started to decrease gradually, returning to near-baseline values 180 min postinfusion. The ACTH infusion also caused an increase in glucose and fatty acids concentrations to a peak of $4.4 \pm 0.14$ and $0.6 \pm 0.06 \mathrm{mM}$, respectively. Both glucose and fatty acid concentrations fluctuated over time, reaching a maximum increase of 13 and $100 \%$ for glucose and fatty acid, respectively, but returned to values similar to basal concentrations at the end of the AST (210 min). Basal cortisol was not correlated with basal glucose, fatty acids, or any performance parameters. Cortisol $\mathrm{T}_{\text {peak }}$ was positively correlated with FE $(\mathrm{r}=0.42 ; P=0.034)$.

\section{DISCUSSION}

The central aim of our experiment was to determine whether differential productivity in dairy goats was re-

Table 3. Plasma glucose, insulin, and fatty acids responses to a glucose infusion $(0.3 \mathrm{~g} / \mathrm{kg}$ of BW $)$ performed in high- $(\mathrm{HY} ; 4.0 \mathrm{~L} / \mathrm{d}, \mathrm{n}=13)$ and low-yielding $(\mathrm{LY} ; 2.4 \mathrm{~L} / \mathrm{d}, \mathrm{n}=13)$ dairy goats at $\sim 43 \mathrm{DIM}^{1}$

\begin{tabular}{|c|c|c|c|c|}
\hline Item & HY & LY & $\mathrm{SED}^{2}$ & $P$-value \\
\hline \multicolumn{5}{|l|}{ Glucose } \\
\hline Basal $(\mathrm{m} M)$ & 3.0 & 3.4 & 0.18 & $0.046^{*}$ \\
\hline Peak $(\mathrm{m} M)$ & 15.6 & 17.2 & 0.66 & $0.009^{*}$ \\
\hline Nadir $(\mathrm{m} M)$ & 2.1 & 2.3 & 0.19 & 0.250 \\
\hline Change $^{3}(\%)$ & 418 & 426 & 27.0 & 0.775 \\
\hline Recovery $^{4}(\mathrm{~m} M)$ & 2.9 & 3.3 & 0.19 & $0.013^{*}$ \\
\hline $\mathrm{T}_{1 / 2}^{5}(\mathrm{~min})$ & 30 & 32 & 1.7 & 0.385 \\
\hline $\mathrm{T}_{\text {basal }}{ }^{6}(\mathrm{~min})$ & 80 & 84 & 4.2 & 0.567 \\
\hline $\mathrm{CR}_{2-30}{ }^{7}(\% / \mathrm{min})$ & 2.4 & 2.3 & 0.16 & 0.598 \\
\hline $\mathrm{CR}_{30-60}(\% / \mathrm{min})$ & 2.1 & 2.0 & 0.24 & 0.859 \\
\hline $\mathrm{AUC}_{0-60}(\mathrm{~m} M \cdot \min )$ & 316 & 361 & 20.4 & $0.012^{*}$ \\
\hline $\mathrm{AUC}_{0-120}(\mathrm{~m} M \cdot \mathrm{min})$ & 324 & 394 & 45.5 & 0.068 \\
\hline \multicolumn{5}{|l|}{ Insulin } \\
\hline Basal (mU/L) & 5.6 & 12.9 & 2.51 & $0.008^{*}$ \\
\hline Peak $(\mathrm{mU} / \mathrm{L})$ & 78.1 & 115.2 & 24.7 & 0.097 \\
\hline $\operatorname{Nadir}(\mathrm{mU} / \mathrm{L})$ & 3.3 & 7.9 & 1.87 & 0.016 \\
\hline Change $(\%)$ & 4,695 & 1,354 & 2,387 & 0.174 \\
\hline Recovery $(\mathrm{mU} / \mathrm{L})$ & 4.3 & 10.3 & 1.85 & $0.004^{*}$ \\
\hline $\mathrm{T}_{\text {peak }}^{9}(\min )$ & 19 & 20 & 1.4 & 0.782 \\
\hline $\mathrm{T}_{\text {basal }}(\min )$ & 117 & 119 & 6.5 & 0.842 \\
\hline $\mathrm{CR}_{30-60}(\% / \min )$ & 2.8 & 1.9 & 0.43 & $0.042^{*}$ \\
\hline $\mathrm{AUC}_{0-60}(\mathrm{mU} / \mathrm{L} \cdot \mathrm{min})$ & 3,453 & 4,974 & 667.0 & 0.120 \\
\hline $\mathrm{AUC}_{0-120}(\mathrm{mU} / \mathrm{L} \cdot \mathrm{min})$ & 3,919 & 6,203 & 819.9 & 0.061 \\
\hline \multicolumn{5}{|l|}{ Fatty acids } \\
\hline Basal $(\mathrm{m} M)$ & 0.6 & 0.5 & 0.15 & 0.376 \\
\hline Peak $(\mathrm{m} M)$ & 1.2 & 0.9 & 0.20 & 0.188 \\
\hline Nadir $(\mathrm{m} M)$ & 0.3 & 0.2 & 0.04 & 0.088 \\
\hline Change (\%) & 127 & 102 & 25.2 & 0.283 \\
\hline Recovery $(\mathrm{m} M)$ & 1.0 & 0.7 & 0.19 & 0.137 \\
\hline $\mathrm{AUC}_{0-60}(\mathrm{~m} M \cdot \min )$ & -6.3 & -3.9 & 2.9 & 0.568 \\
\hline $\mathrm{AUC}_{0-120}(\mathrm{~m} M \cdot \min )$ & -11.7 & -8.2 & 7.0 & 0.728 \\
\hline
\end{tabular}

${ }^{1}$ Values are restricted maximum likelihood means.

${ }^{2} \mathrm{SED}=$ standard error of differences.

${ }^{3}$ Maximum increase relative to baseline concentration.

${ }^{4}$ Concentration at time 240 min relative to glucose infusion.

${ }^{5}$ Time to reach half-life concentration after the glucose infusion.

${ }^{6}$ Time to reach basal concentration after the glucose infusion.

${ }^{7} \mathrm{CR}=$ clearance rate.

${ }^{8} \mathrm{AUC}=$ area under the response curve.

${ }^{9}$ Tpeak $=$ Time to reach peak concentration after the glucose infusion.

*Statistically significant $(P<0.05)$. 
Table 4. Glucose and insulin MINMOD ${ }^{1}$ parameters derived from intravenous glucose tolerance tests performed in high- $(\mathrm{HY} ; 4.0 \mathrm{~L} / \mathrm{d} ; \mathrm{n}=13)$ and low-yielding $(\mathrm{LY} ; 2.4 \mathrm{~L} / \mathrm{d} ; \mathrm{n}=13)$ dairy goats at $\sim 43 \mathrm{DIM}$

\begin{tabular}{lcccl}
\hline Item $^{2}$ & \multicolumn{1}{c}{$\mathrm{HY}$} & $\mathrm{LY}$ & $\mathrm{SED}^{3}$ & $P$-value \\
\hline $\mathrm{G}_{\mathrm{B}}{ }^{4}(\mathrm{~m} M)$ & $2.8(2.4,3.4)$ & $3.0(2.8,3.3)$ & - & 0.443 \\
$\mathrm{I}_{\mathrm{B}}(\mathrm{mU} / \mathrm{L})$ & 5.3 & 12.5 & 2.45 & $0.008^{*}$ \\
$\mathrm{~S}_{\mathrm{G}}{ }^{4}\left(\mathrm{~min}^{-1}\right)$ & $0.02(0.01,0.02)$ & $0.01(0.01,0.02)$ & - & 0.229 \\
$\mathrm{~S}_{\mathrm{I}}\left[(\mathrm{mU} / \mathrm{L})^{-1} \cdot \mathrm{min}^{-1}\right]$ & 3.4 & 4.4 & 1.51 & 0.505 \\
$\mathrm{AIR}\left(\mathrm{mU} \cdot \mathrm{L}^{-1} \cdot \mathrm{min}^{-1}\right)$ & 352 & 536 & 87.5 & $0.047^{*}$ \\
$\mathrm{DI}$ & 2,903 & 1,578 & $1,501.2$ & 0.409 \\
$\mathrm{IR}^{4}\left(\mathrm{~m} M \cdot \mathrm{mU} \cdot \mathrm{L}^{-2}\right)$ & $0.4(0.2,0.9)$ & $1.3(0.8,2.2)$ & - & $0.010^{*}$ \\
$\mathrm{BCF}^{4}(\mathrm{mU} / \mathrm{m} M)$ & $83(33,213)$ & $619(208,1847)$ & - & $0.006^{*}$ \\
\hline
\end{tabular}

${ }^{1}$ MINMOD Millennium, a Windows-based software developed to mathematically describe the dynamic relationship between insulin and glucose during an intravenous glucose tolerance test (Boston et al., 2003). Values are restricted maximum likelihood means.

${ }^{2} \mathrm{G}_{\mathrm{B}}=$ basal glucose, $\mathrm{I}_{\mathrm{B}}=$ basal insulin, $\mathrm{S}_{\mathrm{G}}=$ glucose effectiveness, $\mathrm{S}_{\mathrm{I}}=$ insulin sensitivity, $\mathrm{AIR}=$ acute insulin response to glucose, $\mathrm{DI}=$ disposition index, $\mathrm{IR}=$ insulin resistance, and $\mathrm{BCF}=$ pancreatic $\beta$-cell function.

${ }^{3} \mathrm{SED}=$ standard error of differences.

${ }^{4}$ Back-transformed values with $95 \%$ CI presented in parentheses (lower limit, upper limit).

*Statistically significant $(P<0.05)$.

lated to differences in some aspects of the regulation of energy metabolism. Our experiment used 3 metabolic challenges (glucose, insulin, and $\mathrm{ACTH}$ ) to examine interrelationships between hormones and metabolite concentration and production performance in earlylactation dairy goats.
Our results demonstrated that, along with the increased milk yield, HY goats also had significantly greater DMI and, most importantly, improved FE. However, because FE is described as kilogram of DMI divided by kilogram of milk produced per day, FE can be overestimated when body reserves are mobilized to

Table 5. Spearman rho correlations between performance traits ${ }^{1}$ and glucose and insulin parameters derived from an intravenous glucose tolerance test performed in commercial dairy goats at $\sim 43$ DIM

\begin{tabular}{|c|c|c|c|c|c|c|}
\hline Item & $\begin{array}{l}\text { ECM } \\
(\mathrm{kg} / \mathrm{d})\end{array}$ & $\begin{array}{c}\text { DMI } \\
(\% \mathrm{BW})\end{array}$ & $\begin{array}{c}\mathrm{FE} \\
(\mathrm{kg} / \mathrm{kg})\end{array}$ & $\begin{array}{c}\text { BWE } \\
(\%)\end{array}$ & $\begin{array}{l}\text { BW } \\
(\mathrm{kg})\end{array}$ & BCS \\
\hline \multicolumn{7}{|l|}{ Basal } \\
\hline Insulin $(\mathrm{m} M)$ & $-0.54^{* *}$ & $-0.55^{* *}$ & NS & $-0.54^{* *}$ & NS & $0.59^{* *}$ \\
\hline \multicolumn{7}{|l|}{ Change $^{2}$} \\
\hline Glucose (\%) & NS & NS & NS & NS & NS & NS \\
\hline Insulin (\%) & NS & NS & NS & NS & NS & NS \\
\hline Insulin $(\mathrm{m} M \cdot \min )$ & $-0.54^{* *}$ & $-0.62^{* *}$ & NS & $-0.56^{* *}$ & NS & $0.66^{* * *}$ \\
\hline \multicolumn{7}{|l|}{$\mathrm{CR}_{30-60}$} \\
\hline Glucose $(\% / \mathrm{min})$ & NS & NS & $0.35^{\dagger}$ & NS & $-0.36^{\dagger}$ & NS \\
\hline Insulin $(\% / \min )$ & NS & $0.36^{\dagger}$ & $0.37^{\dagger}$ & $0.48^{*}$ & $-0.65^{* *}$ & $-0.41^{*}$ \\
\hline Glucose/insulin ratio & $0.51^{*}$ & $0.56^{* *}$ & NS & $0.52^{* *}$ & NS & $-0.61^{* *}$ \\
\hline Fatty acids/insulin ratio & $0.35^{\dagger}$ & $0.35^{\dagger}$ & NS & $0.36^{\dagger}$ & NS & $-0.51^{* *}$ \\
\hline \multicolumn{7}{|l|}{ MINMOD $^{5}$} \\
\hline $\mathrm{BCF}(\mathrm{mU} / \mathrm{m} M)$ & $0.41^{*}$ & $0.42^{*}$ & NS & $0.44^{*}$ & NS & $-0.42^{*}$ \\
\hline
\end{tabular}

${ }^{1} \mathrm{FE}=$ feed efficiency rate $[\mathrm{ECM}(\mathrm{kg} / \mathrm{d}) / \mathrm{DMI}(\mathrm{kg} / \mathrm{d})]$, BWE = body weight efficiency $\left[\mathrm{ECM}(\mathrm{kg} / \mathrm{d}) / \mathrm{BW}^{0.75}(\mathrm{~kg}) \times 100\right]$.

${ }^{2}$ Maximum increase relative to the basal concentration.

${ }^{3} \mathrm{AUC}=$ area under the curve.

${ }^{4} \mathrm{CR}=$ clearance rate.

${ }^{5}$ MINMOD $=$ a Windows-based software developed to mathematically describe the dynamic relationship between insulin and glucose during an intravenous glucose tolerance test (Boston et al., 2003). $\mathrm{S}_{\mathrm{G}}=$ glucose effectiveness, $\mathrm{S}_{\mathrm{I}}=$ insulin sensitivity, AIR $=$ acute insulin response to glucose, $\mathrm{DI}=$ disposition index, $\mathrm{IR}=$ insulin resistance, $\mathrm{BCF}=$ pancreatic $\beta$-cell function.

*** $P<0.001$; ** $P<0.01$; $P<0.05 ; \dagger P<0.1 ; \mathrm{NS}=P>0.1$. 

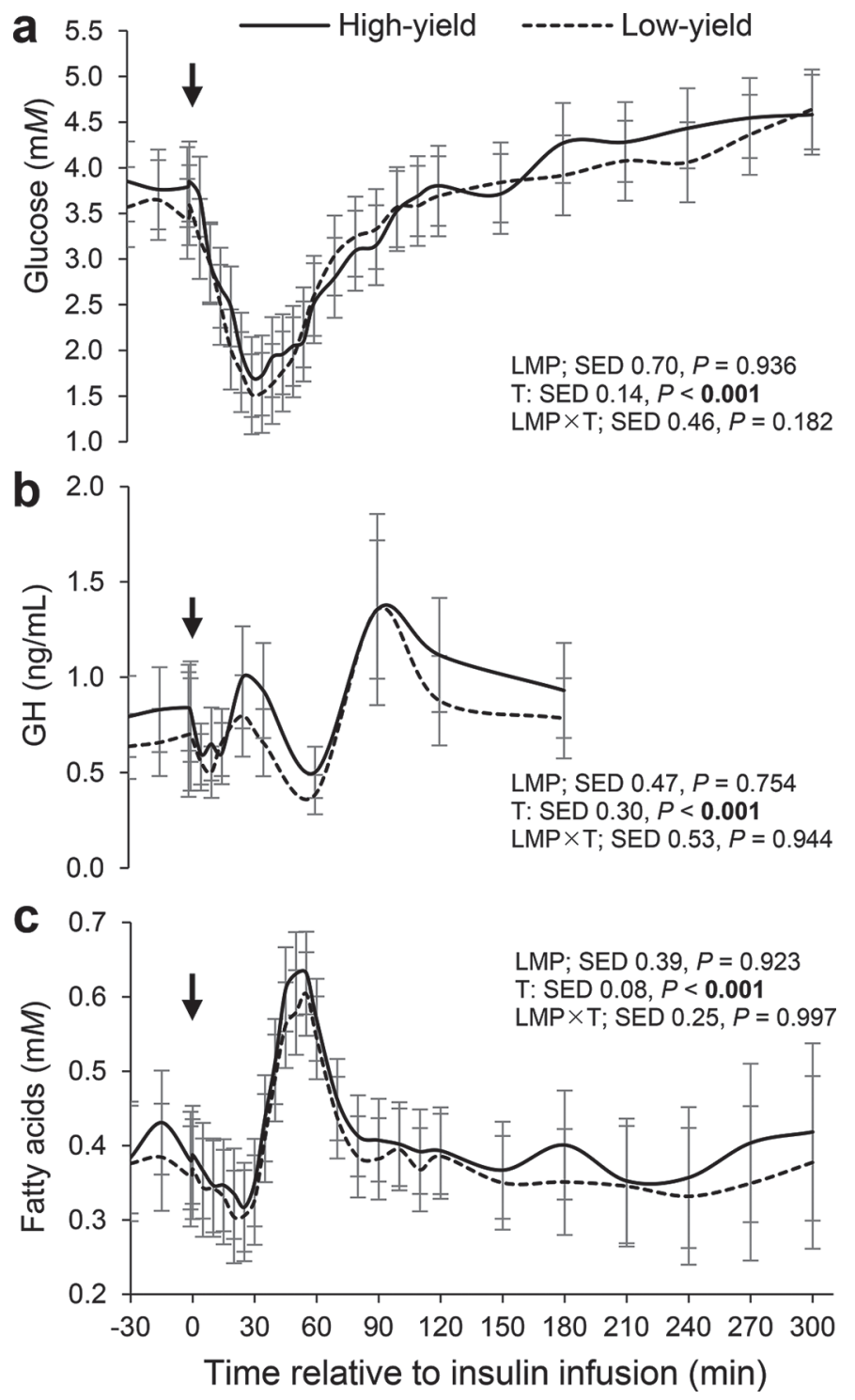

Figure 2. Responses in (a) plasma glucose, (b) growth hormone $(\mathrm{GH})$, and (c) fatty acid concentrations to an insulin infusion (0.125 $\mathrm{IU} / \mathrm{kg}$ of BW) at time zero $(\downarrow)$ in high-yielding $(4.0 \mathrm{~L} / \mathrm{d}, \mathrm{n}=13)$ and low-yielding $(2.4 \mathrm{~L} / \mathrm{d}, \mathrm{n}=13)$ dairy goats at $45 \pm 0.7 \mathrm{DIM}$. Values are restricted maximum likelihood means, and error bars represent SEM. LMP = level of milk production; $\mathrm{T}=$ time of sampling; LMP $\times \mathrm{T}=$ joint effect of LMP and $\mathrm{T} ; \mathrm{SED}=$ pooled standard errors of differences.

sustain increased milk production (Bach et al., 2020). According to Dunshea et al. (1990), fatty acids concentration provides a better estimate of body-fat loss in early lactation than BW variations alone because, as lactation advances, goats increase DMI, thereby increasing gut fill such that total BW might not change. Although we did not observe significant differences in ADG or BW between groups, the inferior BCS and greater fatty acids concentration in HY goats suggest greater lipid mobilization in HY than LY goats, which might have contributed (to some extent) to the improved $\mathrm{FE}$ and BWE observed in HY goats.

The ability to proportionally direct more of absorbed nutrients toward milk synthesis, and less to body reserves, is one of the most critical mechanisms in determining improved milk yield (Baumgard et al., 2017; Bach et al., 2020). Insulin action and glucose transporters (GLUT) play a pivotal role in the regulation of nutrient partitioning during lactation (Bell and Bauman, 1997). For instance, the expression GLUT-1 (non-insulin-dependent), which is the predominate glucose carrier in the mammary gland of lactating cows and rodents (Zhao and Keating, 2007), is substantially increased (4-fold) in mammary epithelial cells of earlycompared with late-lactation goats ( $\mathrm{Na}$ et al., 2009). However, the expression of GLUT-4 (insulin-dependent), which virtually disappears in mammary epithelial cells of lactating cows (Zhao and Keating, 2007), is also reportedly downregulated in skeletal muscle of lactating goats (Balage et al., 1997). Therefore, a state of decreased pancreatic insulin secretion or reduced sensitivity of peripheral tissues to the metabolic actions of insulin would result in reduced glucose utilization by extramammary tissues, thereby favoring substrate availability for milk synthesis (Jaakson et al., 2013; Cincović et al., 2018). Based on these principles, we hypothesized that HY goats would exhibit a greater degree of insulin resistance than LY goats.

According to De Koster and Opsomer (2013), based on data from an IVGTT, insulin resistance can be identified when glucose CR is low, glucose AUC is high, and the glucose $T_{1 / 2}$ and $T_{\text {base }}$ are high. Interestingly, even though HY goats had significantly less basal glucose and insulin concentration than LY goats, values of glucose for $\mathrm{CR}, \mathrm{T}_{1 / 2}, \mathrm{~T}_{\text {base }}$, and maximum change (\%) from basal concentrations were comparable between groups. These results were further supported by results from MINMOD showing that, despite the observed positive association between ECM and $\mathrm{S}_{\mathrm{G}}(\mathrm{r}=0.49)$, and between ECM and DI $(r=0.45)$, there were no measurable differences in $\mathrm{S}_{\mathrm{I}}, \mathrm{S}_{\mathrm{G}}$, and DI between groups, which is inconsistent with our first hypothesis that HY goats would have a lesser glucose-induced insulin secretion during the IVGTT. Moreover, the lesser calculated IR $(-69 \% ; P=0.010)$, and lesser glucose $\mathrm{AUC}_{0-60}(-12 \%$; $P=0.012)$ in HY goats was indicative of a less insulinresistant state in this group, which contrasts with what has generally been accepted in high-yielding dairy cows (De Koster and Opsomer, 2013; Baumgard et al., 2017; Cincović et al., 2018).

However, it should be emphasized that glucose disappearance during the IVGTT is the result of both glucose uptake by the insulin-sensitive tissues (e.g., muscle and adipose tissue), and by insulin-insensitive 
Table 6. Plasma glucose, growth hormone, and fatty acids responses to insulin infusion $(0.125 \mathrm{IU} / \mathrm{kg}$ of BW $)$ performed in high- $(\mathrm{HY} ; 4.0 \mathrm{~L} / \mathrm{d}, \mathrm{n}=13)$ and low-yielding $(\mathrm{LY} ; 2.4 \mathrm{~L} / \mathrm{d}, \mathrm{n}=13)$ dairy goats at $\sim 44 \mathrm{DIM}^{1}$

\begin{tabular}{|c|c|c|c|c|}
\hline Item & HY & LY & $\mathrm{SED}^{2}$ & $P$-value \\
\hline \multicolumn{5}{|l|}{ Growth hormone } \\
\hline Basal (ng/mL) & 1.4 & 1.3 & 0.29 & 0.707 \\
\hline Peak (ng/mL) & 3.6 & 3.5 & 0.65 & 0.900 \\
\hline Nadir (ng/mL) & 0.5 & 0.4 & 0.20 & 0.717 \\
\hline Change $^{3}(\%)$ & 400 & 112 & 116.7 & 0.021 \\
\hline $\mathrm{T}_{\text {peak }}^{4}(\min )$ & 69 & 98 & 18.5 & 0.123 \\
\hline $\mathrm{AUC}_{0-120}{ }^{5}(\mathrm{ng} / \mathrm{mL} \cdot \mathrm{min})$ & 33.2 & 55.7 & 39.12 & 0.571 \\
\hline \multicolumn{5}{|l|}{ Glucose } \\
\hline Basal $(\mathrm{m} M)$ & 4.1 & 3.8 & 0.26 & 0.515 \\
\hline Peak $(\mathrm{m} M)$ & 4.5 & 4.3 & 0.39 & 0.729 \\
\hline Nadir $(\mathrm{m} M)$ & 1.6 & 1.4 & 0.19 & 0.580 \\
\hline Change (\%) & -62 & -63 & 3.4 & 0.818 \\
\hline $\mathrm{T}_{1 / 2}^{6}(\min )$ & 27 & 26 & 3.9 & 0.866 \\
\hline $\mathrm{CR}_{5-30}{ }^{7}(\% / \mathrm{min})$ & 3.0 & 2.9 & 0.27 & 0.785 \\
\hline $\mathrm{AUC}_{0-120}(\mathrm{~m} M \cdot \min )$ & -146.4 & -121.0 & 18.71 & 0.232 \\
\hline \multicolumn{5}{|l|}{ Fatty acids } \\
\hline Basal $(\mathrm{m} M)$ & 0.3 & 0.3 & 0.05 & 0.723 \\
\hline Peak $(\mathrm{m} M)$ & 0.7 & 0.6 & 0.07 & 0.647 \\
\hline Nadir $(\mathrm{m} M)$ & 0.2 & 0.2 & 0.03 & 0.712 \\
\hline Change (\%) & 147 & 140 & 41.1 & 0.882 \\
\hline $\mathrm{T}_{\text {peak }}(\min )$ & 56 & 67 & 12.4 & 0.398 \\
\hline $\mathrm{AUC}_{0-120}(\mathrm{~m} M \cdot \min )$ & 7.0 & 7.3 & 4.12 & 0.947 \\
\hline
\end{tabular}

${ }^{1}$ Values are restricted maximum likelihood means.

${ }^{2} \mathrm{SED}=$ standard error of differences.

${ }^{3}$ Maximum increase or decrease relative to baseline concentration.

${ }^{4}$ Time to reach peak concentration after the insulin infusion.

${ }^{5} \mathrm{AUC}=$ area under the response curve.

${ }^{6}$ Time to reach half-life concentration after the insulin infusion.

${ }^{7} \mathrm{CR}=$ clearance rate.

tissues (e.g., mammary gland, brain, kidneys, immune cells; De Koster and Opsomer, 2013; Kvidera et al., 2017). Thus, these apparently conflicting results may be attributable to the greater demand for glucose placed by the mammary gland of HY compared with LY goats, which would consequently influence the glucose dynamics during the IVGTT. Moreover, a proper interpretation of an IVGTT presupposes similar insulin secretion between animals (De Koster and Opsomer, 2013), which does not seem to be the case in our study given the observed differences in basal insulin, AIR, and BCF. Hence, based on the IVGTT results only, no conclusions could be drawn on whether HY and LY goats exhibited a different degree of insulin resistance.

The ITT is commonly used to evaluate insulin sensitivity of insulin-responsive tissues (Wilcox, 2005; Davis et al., 2017; Marett et al., 2017), but it is also useful for assessing GH responses to insulin-induced hypoglycemia (Marett et al., 2014). In this study, results from the ITT indicated similar responses to insulin in both groups, which is inconsistent with our second hypothesis that HY goats would exhibit lesser glucose and fatty acids responses during the ITT. These results suggested that the lesser milk production in LY goats may be more closely related to greater insulin secretion than to differences in whole-body sensitivity to insulin between LY and HY goats. This is supported by the negative association between EMC and basal insulin, insulin $\mathrm{AUC}_{0-120}$, and $\mathrm{AIR}(\mathrm{r}=-0.41$ to -0.54$)$, and is in accordance with findings of Hammon et al. (2007), in which milk yield from crossbred dairy heifers (at 30 DIM) was negatively correlated with both basal insulin $(\mathrm{r}=-0.30)$ and insulin AUC $(\mathrm{r}=-0.35)$. Similarly, Shingu et al. (2002) demonstrated that dairy cows have markedly lesser glucose-induced insulin secretion than beef cows, regardless of the stage of lactation. Present and previous results endorse an inverse relationship between milk yield and insulin secretion, regardless of whether the increased milk yield was due to greater genetic merit between or within breeds.

Previous work in humans (Wilcox, 2005; Keane and Newsholme, 2014) and in dairy cows (De Koster and Opsomer, 2013; Cincović et al., 2018) have reported a negative association between fatty acids concentration and pancreatic insulin secretion. In the present study, differences in insulin secretion could not be explained by differences in fatty acids concentration because basal fatty acids concentration was comparable between HY and LY goats on the day of IVGTT, ITT, and AST. However, Keane and Newsholme (2014) stated that 
Table 7. Plasma cortisol, glucose, and fatty acid responses to an adrenocorticotropic hormone infusion $(0.2 \mathrm{IU} / \mathrm{kg}$ of $\mathrm{BW})$ performed in high- (HY; 4.0 L/d, $\mathrm{n}=13$ ) and low-yielding (LY; $2.4 \mathrm{~L} / \mathrm{d}, \mathrm{n}=13)$ dairy goats at $\sim 45 \mathrm{DIM}^{1}$

\begin{tabular}{|c|c|c|c|c|}
\hline Item & HY & LY & $\mathrm{SED}^{2}$ & $P$-value \\
\hline \multicolumn{5}{|l|}{ Cortisol } \\
\hline Basal (ng/mL) & 6.8 & 8.0 & 2.1 & 0.557 \\
\hline Peak (ng/mL) & 103.4 & 102.5 & 10.1 & 0.933 \\
\hline Nadir $(\mathrm{ng} / \mathrm{mL})$ & 12.2 & 14.2 & 2.3 & 0.464 \\
\hline Change $^{3}(\%)$ & 2,048 & 1,871 & 602.0 & 0.755 \\
\hline $\mathrm{T}_{\text {peak }}{ }^{4}(\mathrm{~min})$ & 48 & 42 & 5.9 & 0.237 \\
\hline \multicolumn{5}{|l|}{ Glucose } \\
\hline Basal $(\mathrm{m} M)$ & 3.8 & 4.0 & 0.30 & 0.357 \\
\hline Peak $(\mathrm{m} M)$ & 4.3 & 4.5 & 0.28 & 0.618 \\
\hline Nadir $(\mathrm{m} M)$ & 3.2 & 3.4 & 0.19 & 0.231 \\
\hline Change (\%) & 16 & 12 & 3.3 & 0.250 \\
\hline \multicolumn{5}{|l|}{ Fatty acids } \\
\hline Basal $(\mathrm{m} M)$ & 0.3 & 0.3 & 0.08 & 0.723 \\
\hline Peak $(\mathrm{m} M)$ & 0.7 & 0.6 & 0.11 & 0.662 \\
\hline Nadir $(\mathrm{m} M)$ & 0.2 & 0.2 & 0.05 & 0.808 \\
\hline Change (\%) & 136 & 128 & 42.9 & 0.848 \\
\hline
\end{tabular}

${ }^{1}$ Values are restricted maximum likelihood means.

${ }^{2} \mathrm{SED}=$ standard error of differences.

${ }^{3}$ Maximum increase relative to baseline concentration.

${ }^{4}$ Time to reach peak concentration after the ACTH infusion.

prolonged exposure to elevated concentrations of fatty acids might chronically decrease glucose-stimulated insulin secretion in rats and human pancreatic islets. Considering that HY goats had greater plasma fatty acids concentration during the weeks preceding the metabolic challenges, the lesser BCF and AIR in HY goats might reflect long-term effects of increased fatty acids concentration on pancreatic insulin secretory capacity. Nevertheless, the reasons for the present findings remain speculative.

Data from the IVGTT showed that in addition to the lesser AIR, insulin CR in HY was 1.5-fold greater than in LY goats, which indicated that the lesser insulin concentration in HY goats could also be a consequence of the increased insulin degradation in this group. According to Lacasse and Prosser (2003), variations in milk yield are usually accompanied by a similar variation in mammary and hepatic blood flow in goats. Therefore, it is plausible that increased milk yield might have contributed to greater insulin $\mathrm{CR}$ in $\mathrm{HY}$ goats by accelerating insulin clearance by the liver (Reynolds et al., 2003).

Further, counter-regulatory responses to insulininduced hypoglycemia (e.g., glucagon, cortisol, or GH secretion) may affect metabolic responses to an ITT (Malaisse, 2015; Davis et al., 2017; Marett et al., 2017). For instance, GH has insulin-antagonistic effects both in hepatic and peripheral tissues, stimulating lipolysis and gluconeogenesis and inhibiting lipogenesis and glucose uptake, which results in increased nutrient supply to the mammary gland (Bell and Bauman, 1997). Not surprisingly, in dairy cows, increased milk production is associated with elevated basal GH and greater insulin resistance (Bell and Bauman, 1997; Lucy et al., 2009); treatment with exogenous GH has been shown
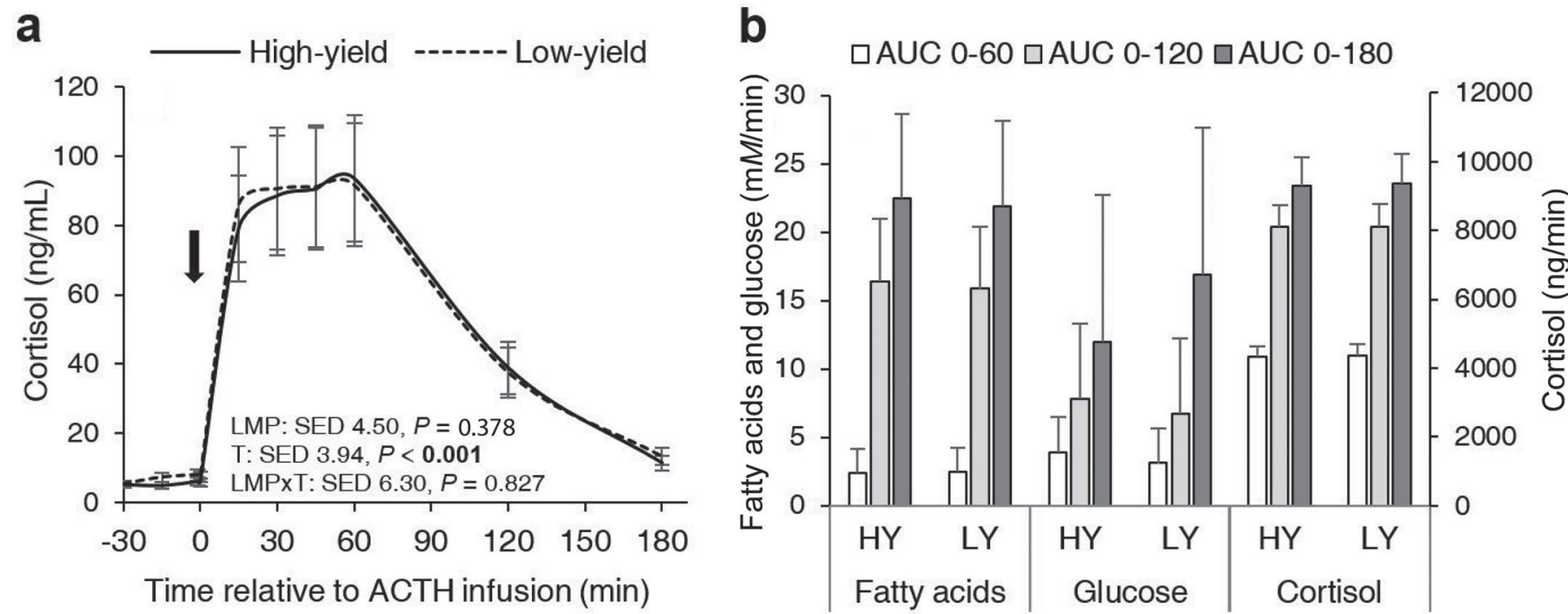

Figure 3. Responses in (a) plasma cortisol to an adrenocorticotropic hormone infusion $(0.2 \mathrm{IU} / \mathrm{kg}$ of BW) at time zero ( $\downarrow$ ), and (b) area under the curve (AUC) for fatty acids, glucose, and cortisol at 60, 120, and 180 min postinfusion in high-yielding $(\mathrm{HY} ; 4.0 \mathrm{~L} / \mathrm{d}, \mathrm{n}=13)$ and low-yielding (LY; $2.4 \mathrm{~L} / \mathrm{d}, \mathrm{n}=13$ ) dairy goats at $46 \pm 0.7 \mathrm{DIM}$. Values are restricted maximum likelihood means, and error bars represent SEM. The $P$-values for AUC 0-60 min, 0-120 min, and 0-180 min were as follows: fatty acids $0.98,0.93$, and 0.95 ; glucose 0.82 , 0.88, and 0.75 ; and cortisol $0.93,0.99$, and $0.96 . \mathrm{LMP}=$ level of milk production; $\mathrm{T}=$ time of sampling; $\mathrm{LMP} \times \mathrm{T}=$ joint effect of $\mathrm{LMP}$ and $\mathrm{T}$; $\mathrm{SED}=$ pooled standard errors of differences. 
to increase milk yield in dairy cows and goats (Chadio et al., 2000; Baldi et al., 2002; Baumgard et al., 2017). Moreover, Marett et al. (2019) demonstrated that GH responses to insulin-induced hypoglycemia tend to be greater in high- than low-yielding cows, and a recent study in male goats has shown that insulin infusion increased plasma GH concentration up to 3-fold shortly after infusion (Nishihara et al., 2017). Given the lesser insulin concentration and the greater milk yield in HY goats, we expected that GH responses to an ITT would be greater in this group. This hypothesis was supported by the greater increase in GH concentration after the insulin infusion in HY compared with LY goats (5.0- vs. 2.1 -fold; $P=0.021$, respectively). However, there was no other evident effect of LMP on GH response to the ITT.

In a recent study (Zamuner et al., 2020), we observed that greater milk yield (2-fold) in early lactation (wk $0-3$ ) was associated with a greater $\mathrm{GH} /$ insulin ratio (3fold) and greater plasma levels of fatty acids and BHB (2-fold) during the same period, and with a greater BW loss from wk 0 to 6 (7.0 vs. $1.0 \%$ of BW loss; $P<0.01$, for HY vs. LY; data not shown), which suggests greater catabolic state and degree of negative energy balance in HY compared with LY goats. Comparatively, the present data showed that HY had greater milk yield (1.7-fold) and slightly greater plasma fatty acids concentration (1.3-fold) during the weeks preceding the challenges. However, at the time of the ITT (wk 6), basal plasma fatty acids were comparable in HY and LY, suggesting similar energy balance across groups. The literature shows that in lactating dairy cows, both basal GH and GH secretory responses increase with increasing merit for milk yield (Shingu et al., 2002; Lucy et al., 2009) and increasing negative energy balance (Bradford and Allen, 2008), but decrease with increasing DIM (Shingu et al., 2002; Marett et al., 2014). Therefore, because the present study goats were tested later in lactation [wk 6 compared with wk 3 of Zamuner et al. (2020)], our ability to detect differences in GH responses between HY and LY goats may have been hindered.

In addition, recent research in dairy cows suggests that decreased ACTH-induced cortisol responses are associated with greater FE (DiGiacomo et al., 2018) and with greater milk yield (Beerda et al., 2004; Gross et al., 2018). Thus, we hypothesized that, compared with LY goats, HY goats would have a lesser cortisol response to AST. However, in the present experiment, cortisol responses to ACTH administration (e.g., AUC, peak concentration, the time of peak, decline pattern) was not related to LMP. These results substantiate previous findings in dairy goats, in which ACTH administration $(0.6-2.5 \mathrm{IU} / \mathrm{kg} \mathrm{BW})$ were not related to changes in milk yield (Shamay et al., 2000; Bomfim et al., 2018). Innate differences in metabolic responsiveness to the catabolic signals of cortisol may affect nutrient partitioning, thereby influencing FE (DiGiacomo et al., 2018). Nevertheless, despite the positive relationship between $\mathrm{T}_{\text {peak }}$ cortisol and $\mathrm{FE}(\mathrm{r}=0.42)$, we found no measurable difference in fatty acids and glucose responses to AST according to LMP, indicating that milk yield was not associated with differential effects of cortisol on carbohydrate and lipid metabolism in $\mathrm{HY}$ and LY goats.

\section{CONCLUSIONS}

The current data show that LY goats exhibit significantly greater pancreatic insulin secretion than $\mathrm{HY}$ goats. On the other hand, there was no evident difference between groups in peripheral tissue responses to glucose, insulin, or ACTH infusion. Hence, the presented results suggest that production efficiency in early-lactation dairy goats is more closely related to differences in the regulation of insulin release and degradation than to differences in peripheral tissue responsiveness to the effects of catabolic and anabolic hormones. The present findings provide insights into the mechanisms that contribute to improved milk yield in dairy goats. However, similar investigations should be carried out at varying stages of lactation to confirm mechanisms of nutrient partitioning responsible for increased milk yield throughout lactation.

\section{ACKNOWLEDGMENTS}

This research was supported by an Australian Government Research Training Program (RTP) Scholarship (Melbourne, VIC, Australia) awarded to Fernanda Zamuner. The authors gratefully acknowledge Meredith Dairy Ltd. (Meredith, VIC, Australia) personnel for their assistance throughout this study. The authors confirm that they do not have any conflicts of interest.

\section{REFERENCES}

Bach, A., M. Terré, and M. Vidal. 2020. Symposium review: Decomposing efficiency of milk production and maximizing profit. J. Dairy Sci. 103:5709-5725. https://doi.org/10.3168/jds.2019-17304.

Balage, M., J. F. Hocquette, B. Graulet, P. Ferré, and J. Grizard. 1997. Skeletal muscle glucose transporter (GLUT-4) protein is decreased in lactating goats. Anim. Sci. J. 65:257-265. https://doi .org/10.1017/S1357729800016568.

Baldi, A., S. Modina, F. Cheli, F. Gandolfi, L. Pinotti, L. B. Scesi, F. Fantuz, and V. Dell'Orto. 2002. Bovine somatotropin administration to dairy goats in late lactation: Effects on mammary gland function, composition and morphology. J. Dairy Sci. 85:1093-1102. https://doi.org/10.3168/jds.S0022-0302(02)74170-2.

Baumgard, L. H., R. J. Collier, and D. E. Bauman. 2017. A 100-year review: Regulation of nutrient partitioning to support lactation. J. Dairy Sci. 100:10353-10366. https://doi.org/10.3168/jds.2017 -13242 . 
Beerda, B., J. E. Kornalijnslijper, J. T. N. Van der Werf, E. N. Noordhuizen-Stassen, and H. Hopster. 2004. Effects of milk production capacity and metabolic status on HPA function in early postpartum dairy cows. J. Dairy Sci. 87:2094-2102. https://doi.org/10 .3168/jds.S0022-0302(04)70027-2

Bell, A. W., and D. E. Bauman. 1997. Adaptations of glucose metabolism during pregnancy and lactation. J. Mammary Gland Biol. Neoplasia 2:265-278. https://doi.org/10.1023/A:1026336505343.

Bomfim, G. F., G. K. F. Merighe, S. A. de Oliveira, and J. A. Negrao. 2018. Effect of acute stressors, adrenocorticotropic hormone administration, and cortisol release on milk yield, the expression of key genes, proliferation, and apoptosis in goat mammary epithelial cells. J. Dairy Sci. 101:6486-6496. https://doi.org/10.3168/ jds.2017-14123.

Boston, R. C., D. Stefanovski, P. J. Moate, A. E. Sumner, R. M. Watanabe, and R. N. Bergman. 2003. MINMOD Millennium: A computer program to calculate glucose effectiveness and insulin sensitivity from the frequently sampled intravenous glucose tolerance test. Diabetes Technol. Ther. 5:1003-1015. https://doi.org/ 10.1089/152091503322641060.

Bradford, B. J., and M. S. Allen. 2008. Negative energy balance increases periprandial ghrelin and growth hormone concentrations in lactating dairy cows. Domest. Anim. Endocrinol. 34:196-203. https://doi.org/10.1016/j.domaniend.2007.02.002.

Cai, J., F. Q. Zhao, J. Liu, and D. Wang. 2018. Local mammary glucose supply regulates availability and intracellular metabolic pathways of glucose in the mammary gland of lactating dairy goats under malnutrition of energy. Front. Physiol. 9:1467. https://doi .org/10.3389/fphys.2018.01467.

Chadio, S. E., G. Zervas, K. Kiriakou, C. Goulas, and J. Menegatos. 2000. Effects of recombinant bovine somatotropin administration to lactating goats. Small Rumin. Res. 35:263-269. https://doi.org/ 10.1016/S0921-4488(99)00104-2.

Cincović, M. R., R. Đoković, B. Belić, I. Lakić, N. Stojanac, O. Stevančević, and N. Staničkov. 2018. Insulin resistance in cows during the periparturient period. Acta Agric. Serb. 23:233-245. https://doi.org/10.5937/AASer1846233C

Cronjé, P. B., M. De Jager, and E. Vlok. 2000. Nutrient partitioning and response to insulin challenge at different planes of nutrition during lactation in goats of high vs. low milk production potential. S. Afr. J. Anim. Sci. 30:178-185. https://doi.org/10.4314/ sajas.v30i3.3850.

Davis, A. N., J. L. Clegg, C. A. Perry, and J. W. McFadden. 2017. Nutrient restriction increases circulating and hepatic ceramide in dairy cows displaying impaired insulin tolerance. Lipids 52:771780. https://doi.org/10.1007/s11745-017-4287-5.

De Koster, J. D., and G. Opsomer. 2013. Insulin resistance in dairy cows. Vet. Clin. North Am. Food Anim. Pract. 29:299-322. https: //doi.org/10.1016/j.cvfa.2013.04.002.

Debras, E., J. Grizard, E. Aina, S. Tesseraud, C. Champredon, and M. Arnal. 1989. Insulin sensitivity and responsiveness during lactation and dry period in goats. Am. J. Physiol. 256:E295-E302. https:// doi.org/10.1152/ajpendo.1989.256.2.E295.

DiGiacomo, K., E. Norris, F. R. Dunshea, B. J. Hayes, L. C. Marett, W. J. Wales, and B. J. Leury. 2018. Responses of dairy cows with divergent residual feed intake as calves to metabolic challenges during midlactation and the nonlactating period. J. Dairy Sci. 101:6474-6485. https://doi.org/10.3168/jds.2017-12569.

Dunshea, F. R., A. Bell, and T. Trigg. 1990. Body composition changes in goats during early lactation estimated using a two-pool model of tritiated water kinetics. Br. J. Nutr. 64:121-131. https://doi .org/10.1079/BJN19900015.

Friggens, N. C., L. Brun-Lafleur, P. Faverdin, D. Sauvant, and O. Martin. 2013. Advances in predicting nutrient partitioning in the dairy cow: Recognizing the central role of genotype and its expression through time. Animal 7(Suppl. 1):89-101. https://doi.org/10 $.1017 / \mathrm{S} 1751731111001820$.

Gross, J. J., R. S. Zbinden, F. Dohme-Meir, and R. M. Bruckmaier. 2018. Adrenal cortex reactivity in dairy cows differs between lactational stages and between different feeding levels. J. Anim.
Physiol. Anim. Nutr. (Berl.) 102:e309-e315. https://doi.org/10 $.1111 /$ jpn.12746.

Hammon, H. M., O. Bellmann, J. Voigt, F. Schneider, and C. Kühn. 2007. Glucose-dependent insulin response and milk production in heifers within a segregating resource family population. J. Dairy Sci. 90:3247-3254. https://doi.org/10.3168/jds.2006-748.

Jaakson, H., K. Ling, J. Samarütel, A. Ilves, T. Kaart, O. Kärt, and M. Ots. 2013. Blood glucose and insulin responses during the glucose tolerance test in relation to dairy cow body condition and milk yield. Vet. Med. Zoot. 62:28-35.

Johnson, M. M., and J. P. Peters. 1993. An improved method to quantify nonesterified fatty acids in bovine plasma. J. Anim. Sci. 71:753-756. https://doi.org/10.2527/1993.713753x.

Keane, K., and P. Newsholme. 2014. Metabolic regulation of insulin secretion. Vitam. Horm. 95:1-33. https://doi.org/10.1016/B978-0 -12-800174-5.00001-6.

Kiplagat, S. K., M. K. Limo, and I. S. Kosgey. 2012. Genetic improvement of livestock for milk production. Pages 77-96 in Milk Production-Advanced Genetic Traits, Cellular Mechanism, Animal Management and Health. N. Chaiyabutr, ed. Intech Publishers. https://doi.org/10.5772/50761.

Köck, A., M. Ledinek, L. Gruber, F. Steininger, B. Fuerst-Waltl, and C. Egger-Danner. 2018. Genetic analysis of efficiency traits in Austrian dairy cattle and their relationships with body condition score and lameness. J. Dairy Sci. 101:445-455. https://doi.org/10.3168/ jds.2017-13281.

Kvidera, S. K., E. A. Horst, M. Abuajamieh, E. J. Mayorga, M. V. S. Fernandez, and L. H. Baumgard. 2017. Glucose requirements of an activated immune system in lactating Holstein cows. J. Dairy Sci. 100:2360-2374. https://doi.org/10.3168/jds.2016-12001.

Lacasse, P., and C. G. Prosser. 2003. Mammary blood flow does not limit milk yield in lactating goats. J. Dairy Sci. 86:2094-2097. https://doi.org/10.3168/jds.S0022-0302(03)73798-9.

Lucy, M. C., G. A. Verkerk, B. E. Whyte, K. A. Macdonald, L. Burton, R. T. Cursons, J. R. Roche, and C. W. Holmes. 2009. Somatotropic axis components and nutrient partitioning in genetically diverse dairy cows managed under different feed allowances in a pasture system. J. Dairy Sci. 92:526-539. https://doi.org/10.3168/ jds.2008-1421.

Maia-Nogueira, D. 2015. The meat goat industry in Australia: Geographical, seasonal and nutritional influences on reproduction in female goats. PhD thesis. College of Public Health, Medical and Veterinary Sciences, James Cook University, Australia. http:// researchonline.jcu.edu.au/41271/.

Malaisse, W. J. 2015. Insulin secretion: Functional biochemical aspects. Pages 95-99 in Encyclopedia of Endocrine Diseases, 2nd ed. I. Huhtaniemi and L. Martini, ed. Academic Press, Oxford, UK. https://doi.org/10.1016/B978-0-12-801238-3.98737-3.

Marett, L. C., M. J. Auldist, P. J. Moate, W. J. Wales, K. L. Macmillan, F. R. Dunshea, and B. J. Leury. 2015. Response of plasma glucose, insulin, and nonesterified fatty acids to intravenous glucose tolerance tests in dairy cows during a 670-day lactation. J. Dairy Sci. 98:179-189. https://doi.org/10.3168/jds.2014-8205.

Marett, L. C., M. J. Auldist, W. J. Wales, K. L. Macmillan, K. DiGiacomo, and B. J. Leury. 2014. Evaluation of growth hormone response to insulin-induced hypoglycaemia in dairy cattle during a 670-day lactation. Anim. Prod. Sci. 54:1323-1327. https://doi .org/10.1071/AN14224.

Marett, L. C., M. J. Auldist, W. J. Wales, K. L. Macmillan, F. R. Dunshea, and B. J. Leury. 2017. Responses of plasma glucose and nonesterified fatty acids to intravenous insulin tolerance tests in dairy cows during a 670-day lactation. J. Dairy Sci. 100:32723281. https://doi.org/10.3168/jds.2016-11985.

Marett, L. C., M. J. Auldist, W. J. Wales, K. L. Macmillan, F. R. Dunshea, and B. J. Leury. 2019. Responses to metabolic challenges in dairy cows with high or low milk yield during an extended lactation. J. Dairy Sci. 102:4590-4605. https://doi.org/10.3168/jds .2018-15513.

Na, Z., L. Qingzhang, G. Xuejun, N. Xuemei, Y. Hongbo, and L. Chun. 2009. Expression and localisation of glucose transporter 1 
(GLUT1) in dairy goat mammary gland at different physiological stages. Can. J. Anim. Sci. 89:475-480. https://doi.org/10.4141/ CJAS09038.

Nishihara, K., R. Kobayashi, Y. Suzuki, K. Sato, K. Katoh, and S. Roh. 2017. Post-prandial decrease in plasma growth hormone levels is not related to the increase in plasma insulin levels in goats. Asian-Australas. J. Anim. Sci. 30:1696-1701. https://doi.org/10 .5713 /ajas.16.0965.

Pires, J. A., A. H. Souza, and R. R. Grummer. 2007. Induction of hyperlipidemia by intravenous infusion of tallow emulsion causes insulin resistance in Holstein cows. J. Dairy Sci. 90:2735-2744. https://doi.org/10.3168/jds.2006-759.

Reynolds, C. K., P. C. Aikman, B. Lupoli, D. J. Humphries, and D. E. Beever. 2003. Splanchnic metabolism of dairy cows during the transition from late gestation through early lactation. J. Dairy Sci. 86:1201-1217. https://doi.org/10.3168/jds.S0022-0302(03)73704 $-7$.

Schmidely, P., M. Lloret-Pujol, P. Bas, A. Rouzeau, and D. Sauvant. 1999. Influence of feed intake and source of dietary carbohydrate on the metabolic response to propionate and glucose challenges in lactating goats. J. Dairy Sci. 82:738-746. https://doi.org/10.3168/ jds.S0022-0302(99)75291-4.

Shamay, A., S. J. Mabjeesh, F. Shapiro, and N. Silanikove. 2000. Adrenocorticotrophic hormone and dexamethasone failed to affect milk yield in dairy goats: comparative aspects. Small Rumin. Res. 38:255-259. https://doi.org/10.1016/S0921-4488(00)00152-8.

Shingu, H., K. Hodate, S. Kushibiki, Y. Ueda, A. Watanabe, M. Shinoda, and M. Matsumoto. 2002. Breed differences in growth hormone and insulin secretion between lactating Japanese Black cows (beef type) and Holstein cows (dairy type). Comp. Biochem. Physiol. C Toxicol. Pharmacol. 132:493-504. https://doi.org/10 .1016/S1532-0456(02)00115-1.
Thomas, G. B., J. E. Mercer, T. Karalis, A. Rao, J. T. Cummins, and I. J. Clarke. 1990. Effect of restricted feeding on the concentrations of growth hormone $(\mathrm{GH})$, gonadotropins, and prolactin (PRL) in plasma, and on the amounts of messenger ribonucleic acid for GH, gonadotropin subunits, and PRL in the pituitary glands of adult ovariectomized ewes. Endocrinology 126:1361-1367. https://doi .org/10.1210/endo-126-3-1361.

Veerkamp, R. F., B. Beerda, and T. van der Lende. 2003. Effects of genetic selection for milk yield on energy balance, levels of hormones, and metabolites in lactating cattle, and possible links to reduced fertility. Livest. Prod. Sci. 83:257-275. https://doi.org/10.1016/ S0301-6226(03)00108-8.

Villaquiran, M., T. A. Gipson, R. C. Merkel, A. L. Goetsch, and T. Sahlu. 2004. Body condition scores in goats. Accessed on Mar. 18, 2016. http://www.luresext.edu/sites/default/files/BCS_factsheet .pdf.

Wilcox, G. 2005. Insulin and insulin resistance. Clin. Biochem. Rev. 26:19-39. https://www.ncbi.nlm.nih.gov/pubmed/16278749.

Zamuner, F., K. DiGiacomo, A. W. N. Cameron, and B. J. Leury. 2020. Endocrine and metabolic status of commercial dairy goats during the transition period. J. Dairy Sci. 103:5616-5628. https:// doi.org/10.3168/jds.2019-18040.

Zhao, F.-Q., and A. F. Keating. 2007. Expression and regulation of glucose transporters in the bovine mammary gland. J. Dairy Sci 90:E76-E86. https://doi.org/10.3168/jds.2006-470.

\section{ORCIDS}

F. Zamuner (® https://orcid.org/0000-0002-9409-8779

B. J. Leury @ https://orcid.org/0000-0001-9173-2730

K. DiGiacomo @ https://orcid.org/0000-0002-6590-3513 